\title{
THE TEREK COSSACKS IN THE CONDITIONS OF "EXTENDING" THE NEW ECONOMIC POLICY: CHANGES IN THE ETHNODEMOGRAPHIC STRUCTURE AND PUBLIC OPINION
}

\author{
Andrey V. Baranov \\ Kuban State University, Krasnodar, Russian Federation
}

\begin{abstract}
Introduction. The subject of this work is the ethno-demographic structure and public opinion of the Terek Cossacks during the period of the NEP "extending". The purpose of the article is to determine the peculiarities of changes in the ethnodemographic structure and public opinion of the Terek Cossacks in the context of "extending" the new economic policy (autumn 1924-1926). Methods and materials. The research methodology includes social constructivism as applied to interpreting the Cossacks' ethnicity. The paper uses the synchronous and diachronic comparative analysis of political orientations of Cossack property layers; a variation series was built on the materials of the All-Union Census of 1926 to identify the total number of the Terek Cossacks and its ethnic identity. Analysis and results. The policy of party-Soviet authorities on "extending" the NEP was carried out on the Terek in part, which was explained by interethnic and land conflicts in the region, the Terek's border strategic location. This conclusion relates to the scale of the amnesty of white movement participants, "revitalization" of local Soviets, easing of policies towards well-off layers of the Cossacks, and their public associations. The response of Terek Cossacks manifested in public opinion developed from the initial hope for democratic elections of councils, cooperatives, land societies (autumn 1924 - spring 1925) to disappointment in inconsistent reforms, to Cossacks' attempts to seize local governments (elections of 1926). The article also proves the predominance of Russian ethnic identity among Terek Cossacks, establishes the territorial structure of their residence area (based on the census of 1926). The author proves the direct proportional relationship between the level of urbanization of the Cossacks living in multiethnic local communities and the choice of Russian identity.
\end{abstract}

Key words: Terek Cossacks, new economic policy, extending, ethnodemography, public opinion.

Citation. Baranov A.V. The Terek Cossacks in the Conditions of "Extending" the New Economic Policy: Changes in the Ethnodemographic Structure and Public Opinion. Vestnik Volgogradskogo gosudarstvennogo universiteta. Seriya 4. Istoriya. Regionovedenie. Mezhdunarodnye otnosheniya [Science Journal of Volgograd State University. History. Area Studies. International Relations], 2019, vol. 24, no. 4, pp. 114-123. (in Russian). DOI: https://doi.org/10.15688/jvolsu4.2019.4.10

УДК 94(470=571)(470.6)

Дата поступления статьи: 01.04.2019

ББК 63(2Рoc-4Кр)

Дата принятия статьи: 21.06.2019

\section{ТЕРСКОЕ КАЗАЧЕСТВО В УСЛОВИЯХ «РАСШИРЕНИЯ» НОВОЙ ЭКОНОМИЧЕСКОЙ ПОЛИТИКИ: ИЗМЕНЕНИЯ ЭТНОДЕМОГРАФИЧЕСКОЙ СТРУКТУРЫ И ОБЩЕСТВЕННОГО МНЕНИЯ}

\section{Андрей Владимирович Баранов}

Кубанский государственный университет, г. Краснодар, Российская Федерация

Аннотация. Предмет работы - этнодемографическая структура и общественное мнение терских казаков в период «расширения» нэпа. Цель статьи - выявить особенности изменений этнодемографической структуры и общественного мнения терского казачества в условиях «расширения» новой экономической 
политики (осень 1924 - 1926 гг.). Методологией исследования выбран социальный конструктивизм применительно к интерпретации этнической принадлежности казачества. В работе применен синхронный и диахронный сравнительный анализ политических ориентаций имущественных слоев казаков; построен вариационный ряд на материалах Всесоюзной переписи населения 1926 г. с целью выявить общую численность терского казачества и его этническую идентичность. Результаты исследования: политика партийно-советских органов власти по «расширению» нэпа проводилась на Тереке в неполном объеме, что объяснялось межэтническими и земельными конфликтами в регионе, приграничным стратегическим расположением Терека. Данный вывод относится к масштабам амнистии участников белого движения, «оживления» местных Советов, смягчения политики в отношении зажиточных слоев казачества, его общественных объединений. Ответная реакция терских казаков, проявившаяся в общественном мнении, развивалась от первоначальной надежды на демократические выборы советов, кооперативов, земельных обществ (осень 1924 - весна 1925 г.) к разочарованию в непоследовательных реформах, к попыткам казаков овладеть местными органами управления (выборы 1926 г.). В статье также доказано преобладание русской этнической идентичности среди терских казаков, установлена территориальная структура ареала их проживания (по материалам переписи 1926 г.). Аргументирована прямо пропорциональная зависимость между уровнем урбанизации казачества, проживанием в полиэтничных местных сообществах и выбором русской идентичности.

Ключевые слова: терское казачество, новая экономическая политика, расширение, этнодемография, общественное мнение.

Цитирование. Баранов А. В. Терское казачество в условиях «расширения» новой экономической политики: изменения этнодемографической структуры и общественного мнения // Вестник Волгоградского государственного университета. Серия 4, История. Регионоведение. Международные отношения. - 2019. - Т. 24, № 4. - C. 114-123. - DOI: https://doi.org/10.15688/jvolsu4.2019.4.10

Введение. Одной из актуальных тем российской истории ХХ в. является взаимодействие власти и многоукладного полиэтничного общества, в том числе такой аспект, как восприятие реформ социальными группами. «Расширение» новой экономической политики (осень 1924 - 1926 г.) остается малоизученным на материалах Терека - обширного историко-культурного региона, отличавшегося переплетением социально-экономических и этнических факторов развития. Терское казачество - интересный и важный объект исследований процессов исторической адаптации и аккультурации русского народа в полиэтничной и поликонфессиональной среде. Тема представляет, на наш взгляд, интерес для междисциплинарного исследования на более широком историческом интервале.

Методы. Цель статьи - выявить особенности изменений этнодемографической структуры и общественного мнения терского казачества в условиях «расширения» новой экономической политики (осень 1924 - 1926 г.). Методологию работы составляет социальный конструктивизм [25], использованный для осмысления этнической идентичности казачества 1920-х годов. В исследовании применяется синхронный и диахронный сравнительный анализ политических ориентаций имуществен- ных слоев терских казаков. На материалах Всесоюзной переписи населения 1926 г. построен вариационный ряд (см. таблицу) с целью выявить общую численность терского казачества, его территориальное размещение и этническую идентичность. Применен также географический метод выявления ареалов и сетей проживания социальных общностей.

Данная тема в современной историографии исследована фрагментарно, прежде всего - в форме кратких упоминаний в обобщающих работах по истории нэпа на Юге России и российском Кавказе. Таковы монографии Я.А. Перехова [16] и Т.В. Панковой-Козочкиной [15]. Среди специальных исследований по истории терского казачества 1920-х гг. доминируют работы о повстанческом движении при переходе к нэпу и депортации сунженских казаков. Среди них выделим по фундированности и новизне монографию Е.Ф. Жупиковой [8], статьи А.К. Кулумбековой [11], В.И. Поматова [19], Ш.О. Рурк [23], диссертацию Е.А. Ткачева [24]. Сложные процессы административно-территориальных реформ 1924-1928 гг. на Тереке и влияние «украинизации» на терское казачество освещены в ценных статьях В.З. Акопяна $[1 ; 2]$. В то же время преобразования «расширения нэпа» на Тереке (осень 1924 - 1926 г.) специально не исследовались. 


\section{Численность терского казачества по Всесоюзной переписи населения} 17 декабря 1926 г.

\begin{tabular}{|c|c|c|c|c|}
\hline Административная единица & $\begin{array}{c}\text { Численность } \\
\text { населения, } \\
\text { тыс. чел. }\end{array}$ & $\begin{array}{c}\text { Численность } \\
\text { казаков, } \\
\text { тыс. чел. }\end{array}$ & $\begin{array}{c}\text { Удельный вес } \\
\text { казаков } \\
\text { в населении, \% }\end{array}$ & $\begin{array}{c}\text { Удельный вес } \\
\text { русских среди } \\
\text { казаков, \% }\end{array}$ \\
\hline Терский округ & 643,4 & 167,3 & 26,0 & 70,4 \\
\hline Городские жители & 184,7 & 26,9 & 14,6 & 77,7 \\
\hline Сельские жители & 458,7 & 140,3 & 30,6 & 69,0 \\
\hline Ставропольский округ & 727,6 & 9,4 & 1,3 & 62,8 \\
\hline Городские жители & 60,4 & 1,5 & 2,4 & 73,3 \\
\hline Сельские жители & 667,1 & 7,9 & 1,2 & 60,8 \\
\hline Сунженский округ $^{1}$ & 34,9 & 27,5 & 78,8 & 97,5 \\
\hline Грозненский округ $^{2}$ & 97,1 & 14,2 & 14,7 & 92,3 \\
\hline Владикавказский округ ${ }^{2}$ & 78,3 & 5,9 & 7,6 & 88,1 \\
\hline Карачаевская автономная область $^{1}$ & 64,6 & 0,6 & 1,0 & 31,7 \\
\hline Черкесский автономный округ ${ }^{1}$ & 37,0 & 0,4 & 1,2 & 50,7 \\
\hline Кабардино-Балкарская автономная область & 204,0 & 8,5 & 4,2 & 45,9 \\
\hline Городские жители & 12,9 & 0,4 & 3,0 & 75,0 \\
\hline Сельские жители & 191,1 & 8,1 & 4,2 & 44,4 \\
\hline Северо-Осетинская автономная область & 152,4 & 14,7 & 9,6 & 38,1 \\
\hline Городские жители & 1,6 & 0,2 & 11,6 & 84,0 \\
\hline Сельские жители & 150,8 & 14,5 & 9,6 & 37,2 \\
\hline Ингушская автономная область & 75,2 & 0,3 & 0,3 & 96,1 \\
\hline Городские жители & 1,3 & 0,035 & 2,8 & 98,4 \\
\hline Сельские жители & 73,9 & 0,2 & 0,3 & 94,7 \\
\hline Чеченская автономная область & 309,9 & 5,5 & 1,8 & 94,6 \\
\hline Городские жители & 3,0 & 0,5 & 15,3 & 96,1 \\
\hline Сельские жители & 306,9 & 5,1 & 1,6 & 92,8 \\
\hline Кизлярский район Дагестанской АССР ${ }^{1}$ & 46,8 & 22,0 & 47,0 & 94,9 \\
\hline Итого & 2471,2 & 276,3 & 11,2 & $\mathbf{7 3 , 9}$ \\
\hline Городские жители & 439,3 & 49,7 & 11,3 & 80,4 \\
\hline Сельские жители & 2031,9 & 226,6 & 11,2 & 69,2 \\
\hline
\end{tabular}

Примечания. Источники: Всесоюзная перепись населения 1926 года. Отд. 1. Народность. Родной язык. Возраст. Грамотность. М. : Изд. ЦСУ Союза ССР, 1928. Т. V. С. 47-50; Казачество Северо-Кавказского края. Итоги переписи населения 1926 г. Ростов н/Д : Сев.-Кавказ. краев. стат. упр-ние. Отд. переписи, 1928. С. 5-9; Районированный Дагестан (административно-хозяйственное деление ДССР по новому районированию 1929 г.). Махачкала : Орготдел ЦИК ДССР, 1930. С. 18.

${ }^{1}$ Административная единица имела только сельское население. ${ }^{2}$ Административная единица имела только городское население.

Вероятно, такое состояние изученности темы во многом объясняется разделенностью корпуса источников из-за территориальных перекроек, оказавшихся в архивохранилищах г. Владикавказа, Ставрополя, Грозного, Пятигорска и др. Значительная часть документов грозненских и ставропольских архивов по данному периоду утрачена. Изложенные обстоятельства повышают необходимость анализа научной проблемы.

Источниковая основа исследования состоит из документов Северо-Кавказского краевого и Терского окружного комитета РКП(б) ВКП(б), Северо-Кавказского краевого и Терского окружного исполнительного комитета $\mathrm{Co}$ - ветов, текстов выступлений партийных и советских функционеров регионального звена, статистических отчетов и сборников, информационных сводок и обзоров ОГПУ, материалов периодической печати. Особое значение имеет статистический сборник «Казачество Северо-Кавказского края. Итоги переписи населения 1926 г.», содержащий данные об уровне урбанизации терского казачества, его этнической и языковой идентичности [10].

Результаты. Переход от «военного коммунизма» к новой экономической политике был на Юге России, в том числе на Тереке, затяжным вследствие рецидивов гражданской войны - повстанческих движений казаков, 
крестьян и горцев (они продолжались до начала 1925 г.) [8, с. 285-325]. Но общая численность терского казачества - 276,3 тыс. чел. в сравнении 1913 и 1926 гг. (см. таблицу) [10, c. 5-9] восстановилась в итоге высокой рождаемости и возврата на Родину многих эмигрантов. Ввиду создания Дагестанской и Горской АССР от бывшей Терской области были отделены г. Грозный и Владикавказ, а также ряд местностей с компактным проживанием терских казаков. В итоге к 1927 г. ареал проживания терских казаков стал разделенным между 13 административно-территориальными единицами, причем 18,8 \% казаков проживали в национальных автономиях Северного Кавказа, а в Терском округе было сосредоточено только $60,6 \%$ терского казачества [10, c. 5-9].

Поскольку регион оставался сельскохозяйственным, в городах проживали лишь $18 \%$ казаков (очаги урбанизации - г. Грозный, Владикавказ и агломерация Кавказских Минеральных вод). Порайонный сравнительный анализ удельного веса казаков в населении доказывает неравномерность и дисперсность ареала расселения. Наивысший процент казачьего населения зафиксирован переписью 1926 г. в Наурском (88,5\%), Суворовском $(71,4 \%)$, Георгиевском (66,3\%), Прохладненском $(64,3 \%)$, Ессентукском (62,4\%), Моздокском (51,1\%) сельских районах Терского округа (в среднем по округу $30,6 \%$ сельских жителей составляли казаки) [10, с. 6-7]. Весьма высокая доля казаков в сельском населении отмечалась также в Сунженском округе $(78,8 \%)$, Петропавловском районе Чеченской автономной области (85,3 \%), Притеречном районе Северо-Осетинской АО (70,5 \%), Казачьем районе Кабардино-Балкарской АО $(70,9 \%)[10$, c. 5-9].

Казаки - городские жители в 1926 г. сосредоточены прежде всего в Ессентуках (47,8 \% всего населения), Моздоке $(26,2 \%)$, Прохладной (16,4 \%), Грозном (14,7 \%), Кисловодске $(13,7 \%)$. В среднем же по ареалу расселения терские казаки составляли $11,3 \%$ горожан [10, с. 5-10]. Географический анализ ареала расселения доказывает размещение сети районов с повышенным удельным весом казаков вдоль границы с автономиями Северного Кавказа (от Каспийского моря до Кара- чая). Уровень урбанизации терских казаков примерно равен таковому для всего населения Северо-Кавказского края.

Другим важным аспектом демографических изменений 1920-х гг. стали сдвиги в этническом самосознании терцев. Если до революции они осознавали себя русскими [10], то в период нэпа проводилась последовательная политика «украинизации» Северо-Кавказского края. Этническая принадлежность теперь фиксировалась при переписи по родному языку родителей опрошенного, а не по его самооценке. Данные манипуляции обеспечили снижение удельного веса русских среди терских казаков (по переписи 1926 г.) с почти 100 до 73,9\%. Остальные были записаны в бланках переписи украинцами. Сравнительный анализ уровня признания русской идентичности по административным единицам, где проживали терские казаки, доказывает повышенный уровень русского самосознания среди казаков-горожан $(80,4 \%)$ в сравнении с сельскими жителями (69,2 \%). Процент казаков, считавших себя русскими, возрастает с запада на восток. Например, русские составляли $31,7 \%$ казаков в Карачае в сравнении с $94,6 \%$ в Чечне [10, с. 5-10]. Проживание в иноэтничной среде (в автономиях) тоже способствовало принятию казаками русской идентичности. Отчасти эта закономерность корректируется повышенным удельным весом казаков-украинцев в Кабардино-Балкарии и Северной Осетии, что объяснимо особенностями географии миграций до 1917 года. Важно территориальное сравнение удельного веса украинцев, считающих русский язык родным. Повсеместно их процент выше в городах (например, 89,1 \% казаков - горожан Терского округа в сравнении с 39,1 \% казаков - сельских жителей) [10, с. 5-6]. Эта закономерность подтверждает конструируемый, а не наследуемый характер этнической самооценки, а также небольшую этническую дистанцию между русскими и украинцами в восприятии самих опрошенных.

Перейдем к анализу другого аспекта темы - восприятия в общественном мнении терских казаков реформ «расширения нэпа» (осень 1924 - 1926 г.). Как известно, данные реформы стали вынужденным ответом партийно-государственной власти на кризис 
нэпа. 25-27 октября 1924 г. пленум ЦК РКП(б) одобрил резолюции о смягчении курса в отношении крестьянства, что выразилось в разрешении долгосрочной аренды земли и расширении прав кооперативов, в допущении частных торговцев к хлебозаготовкам, в частичной амнистии бывших участников белого движения и эмигрантов. Принято также решение отменить подтасованные итоги выборов сельских советов, запретить большевистским партийным организациям и Советам оказывать давление на избирателей. Выборы в станичные и городские Советы в 1925 и 1926 гг. проходили при соблюдении норм закона. На основе данных решений ЦК 17 февраля 1925 г. члены бюро Терского окружного комитета РКП(б) создали комиссию по проведению амнистии, а также совещание при окружном исполкоме по советскому строительству. Списки лиц, лишенных избирательных прав, были сокращены. В развитие курса реформ пленум ЦК РКП(б) в апреле 1925 г. запретил принудительные меры расказачивания, признав основную массу казаков союзником власти. Вследствие амнистии возникла возможность добиться равноправного участия казаков в местных Советах и кооперативах. Казаки получили право служить в территориальных частях РККА [16, с. $32-45 ; 18$, с. 349-351].

Основные причины, обусловившие оценку реформ «расширения нэпа» казаками, коренились в системе землепользования на Юге России, в том числе - на Тереке, равно как и в особенностях социального неравенства. Свыше 60 \% возделываемой площади земель принадлежали казачеству, составляя его трудовые наделы и вызывая сословное неравноправие «иногородних» русских крестьян, а также горцев. Причем уравнительный передел земли между сословными группами («внутриселенное землеустройство») только был начат [4, т. XXII, с. 57, 202-203, 224-225]. Казаки очень слабо были вовлечены в работу на крупных предприятиях промышленности, их занятость в городах оставалась сезонной. Согласно расчетам Л.И. Лакизо на основании переписи населения 1926 г. по совокупности индикаторов (размеры посевов, инвентаря, скота, стоимости имущества), социальная структура казаков всего Северо-Кавказского края включала в себя 17,4 \% хозяйств бедня- ков и батраков, $77,3 \%$ хозяйств середняков и $5,3 \%$ хозяйств «кулаков». В отличие от них, русские «иногородние» крестьяне состояли на $48,3 \%$ из бедноты и батраков; на $46,4 \%$ из середняков, а 5,3 \% были «кулаками» [12, c. 60-61]. Если изучить неравенство по посевам в Терском округе (1926 г., материалы «Гнездовых» обследований), то бедняцкими можно назвать 40,2 \% семей с посевами меньше 4 дес.; середняцкими - 52,3 \% с посевами от 4 до 16 дес.; зажиточными - 7,5\% семей с посевами более 16 дес. на хозяйство [13, с. 4 5]. Следовательно, казаки в сравнении с крестьянами отличались повышенной трудовой зажиточностью, но даже по большевистским упрощенно-классовым подсчетам процент зажиточных - «эксплуататоров» в обеих сословных группах был одинаковым. Сословная сплоченность казаков во многом сохранялась.

Изложенные факты объясняют, почему терские казаки не питали повышенного доверия к партийно-государственным органам власти, проявляя устойчивую оппозиционность в сравнении с «иногородними» крестьянами и рабочими. Вместе с тем середняцкие и зажиточные слои казачества были не прочь воспользоваться ослаблением правящего режима.

«Оживление Советов», предпринятое в феврале - марте 1925 г., привело в Терском округе к росту участия жителей в выборах с 13,2 до 55,2 \%. Удельный вес казаков среди членов станичных Советов округа вырос до $56,2 \%$, среди председателей станичных Советов - до $13,2 \%$, среди членов райисполкомов Советов - до $10,5 \%$ [9, л. 107]. Характерна реакция коммуниста П. Анисимова в письме секретарю окружкома РКП(б) С.О. Котляру на рост влияния казаков: «Веди себя среди казаков по-дружески, по-дипломатически, а смотри за ними в четыре глаза. Если здесь дать полнейшую демократию, нет гарантий, что не будет организовано под маркой Советов войсковое казачье правительство». Вывод автора письма: просить ВЦИК Советов РСФСР не проводить перевыборы в Терском округе [17, л. 32 об.-33]. Конечно, окружное руководство не поддержало подобные предложения, идущие вразрез с линией центральной власти.

После проведения успешных для казачества выборов 1925 г. усилилась сословная и классовая конфликтность. Государственная 
информационная сводка № 4 Терского окружного отдела ОГПУ за 27 января - 11 февраля 1925 г. сообщала о расклейке в ст-це Черноярской воззвания об устранении от власти всех неместных госслужащих. Сводка № 5 за 1125 февраля упоминает слухи в ст-це Зиновьевской о начале войны между США и СССР, а в г. Пятигорске и Горячеводском районе о новом восстании в Грузии. На хут. Андреевском возникли слухи о возврате «старой (царской. - A. Б.) власти, а в ст-це Лысогорской казаки вывесили портреты императора Николая II со словами: «Теперь уже не боимся» $[6$, л. $63,86,95,225]$. В с. Свободненском казаки хотели снять с должностей всех крестьян и коммунистов. Когда это не удалось, то они попытались сорвать предвыборное собрание. Особенно активно такую агитацию вели середняки (ст-цы Ессентукская и Бургустанская) [6, л. 124-128]. На собрании избирателей ст-цы Кисловодской группировка зажиточных казаков (бывших повстанцев и их пособников) во главе с председателем станичного совета желала лишить прав голосования и выступления крестьян, пыталась лишить «иногородних» земли. В г. Прикумске (сейчас г. Буденновск) расширенное собрание членов городского совета решило наделять землей в первую очередь казаков [6, л. 219-221].

Частыми оставались земельные споры между казаками и «иногородними». Так, в мае 1925 г. произошла массовая драка между сословными группами (избито 16 чел.) в ст-це Лысогорской. Причиной стало выделение земли хорошего качества новоселам, что помешало старожилам выгонять скот на пастбища [6, л. 171-172].

Представляют интерес выступления казаков на совещании по оживлению Советов Терского округа 17 февраля 1925 года. Так, казак Бурцев указывал на недоверие беспартийным в Советах, на недовольство засильем арендаторов на рынках. Казаки ст-цы Горячеводской Костенко и Фомин видели причины неявки на выборы в том, что раньше собрания использовались только для сбора налогов; надо убеждать хлеборобов, а не принуждать их [22, с. 28, 29, 39].

В то же время госинфсводка № 11 Терского окружного отдела ОГПУ от 16 апреля 1925 г. отмечает сдвиг к доброжелательному восприятию Советской власти в районах, бывших базой политического бандитизма. Так, собрание избирателей в ст-це Бургустанской отказало в доверии бывшему председателю станичного совета - участнику повстанческих выступлений и избрало вместо него коммуниста. Сословная рознь отсутствовала впервые на выборах в ст-це Кисловодской. 7 мая 1925 г. в ст-це Калиновской прекратил борьбу отряд «бело-зеленых» повстанцев, заявив о признании советской власти и доверии к ней [6, л. 127-128, 174].

Итоги избирательной кампании 1925 г. и первых мер «расширения нэпа» изложены в оперативном закрытом письме секретаря Терского окружкома РКП(б) С.О. Котляра секретарю Северо-Кавказского крайкома РКП(б) А.И. Микояну от 5 июня 1925 года. Котляр писал: «На новые задачи партии казаки смотрят хорошо, но понимают их по-своему». Реформы воспринимались как предоставление прав казачеству в лице станичных сходов и земельных обществ, как шанс захватить землю у «иногородних». Вывод: нужно ускорить уравнительное землеустройство, особенно в казачьих районах; беднейшие слои наделять землей бесплатно для классового расслоения казаков [14, л. 119-124]. В январе 1926 г. Терский окружной исполком Советов принял решение выселить из региона бывших помещиков, что стало первым признаком ограничения реформ [5, л. 49]. Партийное руководство округа признало через месяц, что списки выселяемых составлялись произвольно.

Со своей стороны, казаки стали проявлять разочарование в непоследовательных реформах, пытаться овладеть местными органами управления на выборах весной 1926 года. Например, в ст-це Наурской создана замаскированная оппозиционная группа с участием бывшего председателя стансовета Атарщикова. Накануне выборов ее участники провели домашние собрания, намечая кандидатуры в противовес коммунистам. Однако нормы избирательной системы (косвенное и открытое голосование) не позволили группе достичь большего, чем перевес на станичном собрании. Кандидатуры на районный съезд Советов уже контролировались большевиками, оппозиция смогла провести в члены стансовета 11 человек из всего состава - 69 чело- 
век. Успеха казачья группировка достигла в ст-це Павлодольской, избрав 50 лояльных себе из 59 членов стансовета. В ст-це Луковской оппозиционная группировка сорвала работу местного совета и провела своих представителей в руководство беспартийной конференции хлеборобов [7, л. 119-122, 139]. Резкий протест казаков вызывали практика лишения избирательных прав «честных людей» и уравнительное землеустройство. Так, в с. Левокумском «кулак» заявил на собрании: «на черта нам землеустройство, раз власть не наша, поселили бы царя Михаила, и то лучше было бы». В ст-це Павлодольской казаки вели агитацию против приема в земельное общество крестьян, демонстративно приняв в его состав бывших чиновников и офицеров с Дона и Кубани [7, л. 234].

В итоге выборов местных Советов по Терскому округу (1926 г.) явка казаков на собрания сократилась до $20,1 \%$, а среди членов стансоветов - до 18,7 \% и председателей стансоветов - до $17,1 \%$ [3, с. 343]. Такие изменения стали итогом разочарования зажиточных и середняцких слоев казачества в непоследовательных реформах. Партийно-государственные органы власти с апреля 1926 г. тоже предпочли взять курс на открытую конфронтацию. В частности, 17 апреля 1926 г. члены бюро Терского окружкома РКП(б) приняли резолюцию об очистке курортов от «социально опасных элементов», о необходимости для органов ОГПУ усилить выявление контрреволюционных и антисоветских организаций [20, л. 72 об.]. 6 июля 1926 г. члены бюро Терского окружкома РКП(б) признали необходимой изоляцию контрреволюционных и кулацких группировок, ведущих агитацию на предвыборных собраниях против власти и ее налоговой политики. Окружной отдел ОГПУ получил директиву ходатайствовать перед полномочным представительством ОГПУ по Северо-Кавказскому краю о высылке членов данных группировок во внесудебном порядке, причем до начала избирательной кампании [21, л. 108]. Реально такая высылка состоялась в конце декабря 1926 года. Итак, преобразования зашли в тупик и были свернуты под одновременным давлением «снизу»- зажиточных и середняцких слоев казаков и «сверху»партийного аппарата, все более податливого к леворадикальным уравнительным лозунгам. Социальная база для установления прочного гражданского мира оказалась недостаточной, a реформы - частичными и непрочными.

Выводы. Политика партийно-советских органов власти по «расширению» нэпа (осень 1924 - 1926 г.) проводилась на Тереке в неполном объеме, что объяснялось межэтническими и земельными конфликтами в регионе, приграничным стратегическим расположением Терека. Это доказывается масштабами амнистии участников белого движения, «оживления» местных Советов, смягчения политики в отношении зажиточных слоев казачества, его общественных объединений. Ответная реакция терских казаков, проявившаяся в общественном мнении, развивалась от первоначальной надежды на демократические выборы советов, кооперативов, земельных обществ (осень 1924 - весна 1925 г.) к разочарованию в непоследовательных реформах, к попыткам казаков овладеть местными органами управления (выборы 1926 г.).

Среди терских казаков преобладала (по итогам переписи 1926 г.) русская этническая идентичность, в большей степени - среди горожан, в меньшей - среди станичников. Ареал проживания казаков в 1920-1924 гг. был разделен между Терской губернией (позже - Терским округом) и автономиями Северного Кавказа. Установлена прямо пропорциональная зависимость между уровнем урбанизации казачества, проживанием в полиэтничных местных сообществах и выбором им русской идентичности.

\section{СПИСОК ЛИТЕРАТУРЫ}

1. Акопян, В. 3. Из истории автономизации казачьего населения в национальных регионах Северного Кавказа / В. 3. Акопян // Каспийский регион: политика, экономика, культура. - 2013. № 1 (34). - C. 26-31.

2. Акопян, В. 3. Политика украинизации на Ставрополье в 1920-1930-е годы. Замыслы, осуществление, итоги / В. З. Акопян // Изв. Саратов. ун-та. Новая серия. Серия: История. Международные отношения. -2015 . - Т. 15, вып. 2. - С. 48-56.

3. Баранов, А. В. Многоукладное общество Северного Кавказа в условиях новой экономической политики / А. В. Баранов. - Краснодар : Изд-во Кубан. гос. ун-та, 1999. - 345 с. 
4. Всесоюзная перепись населения 1926 года. Северо-Кавказский край. Отд. 2. Занятия. -М. : Изд-во ЦСУ СССР, 1929. - Т. ХХІІ.-643 с.

5. Выписка из протокола № 131 п. 18 заседания Малого Президиума Терского окружного исполкома от 21 января 1926 г. // (Государственный архив новейшей истории Ставропольского края) ГАНИСК. - Ф. 5938. - Оп. 1. - Д. 11. - Л. 49.

6. Госинфсводки Терского окружного отдела ОГПУ СССР. 1925 г. // ГАНИСК. -Ф. 5938. - Оп. 1. Д. 12. - Л. 63-225.

7. Госинфсводки Терского окружного отдела ОГПУ СССР. 1926 г. // ГАНИСК. - Ф. 5938. - Оп. 1. Д. 21. - Л. 119-145, 234-257.

8. Жупикова, Е. Ф. Повстанческое движение на Северном Кавказе в 1920-1925 гг. / Е. Ф. Жупикова. - М. : Новый хронограф, 2016. - 424 с.

9. Информационный отчет Терского окружного комитета РКП(б) в ЦК РКП(б). Июнь 1925 г. // Российский государственный архив социально-политической истории (РГАСПИ). - Ф. 17. Оп. 16. - Д. 994. - Л. 86-123.

10. Казачество Северо-Кавказского края. Итоги переписи населения 1926 г. - Ростов н/Д : Сев.-Кавказ. краев. стат. упр-ние. Отд. переписи, 1928. -99 c.

11. Кулумбекова, А. К. Из истории выселения терских казаков в 1918-1921 гг. / А. К. Кулумбекова // Известия Кабардино-Балкарского научного центра РАН. - 2014. - № 5 (61). - С. 193-198.

12. Лакизо, Л. И. Характеристика кулачества северокавказской деревни : (По материалам Всесоюзной переписи населения 1926 г.) / Л. И. Лакизо // Известия Северо-Кавказского научного центра высшей школы. Общественные науки. 1980. - № 4. - С. 57-63.

13. Мартынов, М. К. К характеристике социальной дифференциации деревни на Тереке. Социально-экономический очерк / М. К. Мартынов. Пятигорск : Изд-во Терского окружкома ВКП(б), 1928. - 149 c.

14. Оперативное закрытое письмо секретаря Терского окружкома РКП(б) С.О. Котляра секретарю Северо-Кавказского крайкома РКП(б) А.И. Микояну от 5 июня 1925 г. // ГАНИСК. - Ф. 5938. Оп. 1. - Д. 1. - Л. 118-124.

15. Панкова-Козочкина, Т. В. Казачье-крестьянское самоуправление эпохи нэпа: проблемы модернизации властных отношений на Юге России в 1920-е годы / Т. В. Панкова-Козочкина. - Новочеркасск : Лик, 2014. - 308 с.

16. Перехов, Я. А. Власть и казачество: поиски согласия (1920-1926 гг.) / Я. А. Перехов. - Ростов н/Д : Гефест, 1997. - 138 с.

17. Письмо коммуниста П. Анисимова секретарю Терского окружкома РКП(б) С.О. Котляру от 21 января 1925 г. // (ГАНИСК). - Ф. 5938. - Оп. 1. Д. 1. - Л. 32-33.

18. По вопросу о казачестве: Резолюция Пленума ЦК РКП(б) 23-30 апреля 1925 г. // КПСС в резолюциях и решениях съездов, конференций, пленумов ЦК. - 9-е изд., испр. и доп. - М. : Политиздат, 1984. - T. 3. - C. 349-351.

19. Поматов, В. И. Терское казачество и власть в условиях кризиса 1921 г. / В. И. Поматов // Научная мысль Кавказа. - 2016. - № 4 (88). - С. 99-105.

20. Протокол № 23 заседания бюро Терского окружного комитета ВКП(б) от 17 апреля 1926 г. Резолюция о работе Терского окружного отдела ОГПУ // ГАНИСК. - Ф. 5938. - ОП. 1. - Д. 10. Л. 72 об.

21. Протокол № 35 заседания бюро Терского окружного комитета ВКП(б) от 6 июля 1926 г. Резолюция о мерах отдела ОГПУ к контрреволюционным и кулацким группировкам, активно проявляющим себя в деревне // ГАНИСК. - Ф. 5938. - ОП. 1. Д. 10. - Л. 108.

22. Работа совещания по оживлению Советов Терского округа. - Пятигорск : Изд-во Терокрисполкома. - 1925 (№ 7). - 108 с.

23. Рурк, Ш. О. Как отрабатывался механизм репрессий: высылка терских казаков в 1920 году / Ш. О. Рурк // Отечественная история. -2008. - № 5 . C. $97-128$.

24. Ткачев, Е. А. Терское казачество в годы революций и гражданского противостояния (19171923): участие, политические приоритеты, итоги : автореф. дис. ... канд. ист. наук / Ткачев Евгений Алексеевич. - Пятигорск, 2005. - 27 с.

25. Searle, J. The Construction of Social Reality / J. Searle. -N. Y. : Free Press, 1995. - 256 p.

\section{REFERENCES}

1. Akopyan V.Z. Iz istorii avtonomizatsii kazachyego naseleniya $\mathrm{v}$ natsionalnykh regionakh Severnogo Kavkaza [From the History of Autonomisation of the Cossack Population in the National Regions of the North Caucasus]. Kaspiyskiy region: politika, ekonomika, kultura [Caspian Region: Politics, Economics, Culture], 2013, no. 1 (34), pp. 26-31.

2. Akopyan V.Z. Politika ukrainizatsii na Stavropolye v 1920-1930-e gody. Zamysly, osushchestvlenie, itogi [Ukrainization Policy in the Stavropol Region in the 1920s - 1930s. Plans, Implementation, Results]. Izvestiya Saratovskogo universiteta. Novaya seriya. Seriya: Istoriya. Mezhdunarodnye otnosheniya [Bulletin Izvestiya of Saratov University. New Series. Series: History. International Relations], 2015, vol. 15, iss. 2, pp. 48-56. 
3. Baranov A.V. Mnogoukladnoe obshchestvo Severnogo Kavkaza v usloviyakh novoy ekonomicheskoy politiki [Plural Society of the North Caucasus in the Context of the New Economic Policy]. Krasnodar, Izd-vo Kubanskogo gosudarstvennogo universiteta, 1999. $345 \mathrm{p}$.

4. Vsesoyuznaya perepis naseleniya 1926 goda. Severo-Kavkazskiy kray. Otd. 2. Zanyatiya [AllUnion Census of 1926. North Caucasus Region. Division 2. Professions]. Moscow, Izd-vo TsSU SSSR, 1929, vol. 22. 643 p.

5. Vypiska iz protokola № 131 p. 18 zasedaniya Malogo Prezidiuma Terskogo okruzhnogo ispolkoma ot 21 yanvarya $1926 \mathrm{~g}$. [Extract from Protocol no. 131 cl. 18 of the Meeting of the Terek District Executive Committee Small Presidium of January 21, 1926]. Gosudarstvennyy arkhiv noveyshey istorii Stavropolskogo kraya (GANISK) [State Archive of Modern History of Stavropol Kray], F. 5938, Op. 1, D. 11, L. 49.

6. Gosinfsvodki Terskogo okruzhnogo otdela OGPU SSSR. 1925 g. [State Information Summary of the Terek District Department of the All-Union State Political Administration of the USSR. 1925]. Gosudarstvennyy arkhiv noveyshey istorii Stavropolskogo kraya (GANISK) [State Archive of Modern History of Stavropol Kray], F. 5938, Op. 1, D. 12 , L. $63-225$.

7. Gosinfsvodki Terskogo okruzhnogo otdela OGPU SSSR. $1926 \mathrm{~g}$. [State Information Summary of the Terek District Department of the All-Union State Political Administration of the USSR. 1926]. Gosudarstvennyy arkhiv noveyshey istorii Stavropolskogo kraya (GANISK) [State Archive of Modern History of Stavropol Kray], F. 5938, Op. 1, D. 21, L. 119-145, 234-257.

8. Zhupikova E.F. Povstancheskoe dvizhenie na Severnom Kavkaze v 1920-1925 gg. [Rebel Movement in the North Caucasus in 1920-1925]. Moscow, Novyy Khronograf Publ., 2016. 424 p.

9. Informatsionnyy otchet Terskogo okruzhnogo komiteta RKP(b) v TsK RKP(b). Iyun 1925 g. [Information Report of the Terek District Committee of the Russian Communist Party (Bolsheviks) to the Central Committee of the Russian Communist Party (Bolsheviks). June 1925]. Rossiyskiy gosudarstvennyy arkhiv sotsialno-politicheskoy istorii (RGASPI) [Russian State Archive of SocioPolitical History], F. 17, Op. 16, D. 994, L. 86-123.

10. Kazachestvo Severo-Kavkazskogo kraya. Itogi perepisi naseleniya $1926 \mathrm{~g}$. [The Cossacks of the North Caucasus Region. Results of the Census of 1926]. Rostovon-Don, Severo-Kavkazskoe kraevoe statisticheskoe upravlenie, Otdelenie perepisi, 1928.99 p.

11. Kulumbekova A.K. Iz istorii vyseleniya terskikh kazakov v 1918-1921 gg. [From the History of the Eviction of Terek Cossacks in 1918-1921]. Izvestiya Kabardino-Balkarskogo nauchnogo tsentra RAN [News of Kabardino-Balkarian Scientific Center of the Russian Academy of Sciences], 2014, no. 5 (61), pp. 193-198.

12. Lakizo L.I. Kharakteristika kulachestva severokavkazskoy derevni: (Po materialam Vsesoyuznoy perepisi naseleniya 1926 g.) [Characteristic of the Kulaks of the North Caucasian Village (On the Materials of the All-Union Census of 1926)]. Izvestiya Severo-Kavkazskogo nauchnogo tsentra vysshey shkoly. Obshchestvennye nauki, 1980, no. 4, pp. 57-63.

13. Martyinov M.K. K kharakteristike sotsialnoy differentsiatsii derevni na Tereke. Sotsialno-ekonomicheskiy ocherk [To the Characteristics of the Social Differentiation of Terek Villages. Socio-Economic Essay]. Pyatigorsk, Izd-vo Terskogo okruzhkoma VKP(b), 1928.149 p.

14. Operativnoe zakrytoe pismo sekretarya Terskogo okruzhkoma RKP(b) S.O. Kotlyara sekretaryu Severo-Kavkazskogo kraykoma RKP(b) A.I. Mikoyanu ot 5 iyunya 1925 g. [Operational Closed Letter of Secretary of the Terek Regional Committee of the Russian Communist Party (Bolsheviks) S.O. Kotlyar to Secretary of the North Caucasus Regional Committee of the Russian Communist Party (Bolsheviks) A.I. Mikoyan on June 5, 1925]. Gosudarstvennyy arkhiv noveyshey istorii Stavropolskogo kraya (GANISK) [State Archive of Modern History of Stavropol Kray], F. 5938, Op. 1, D. 1, L. 118-124.

15. Pankova-Kozochkina T.V. Kazachyekrestyanskoe samoupravlenie epokhi nepa: problemy modernizatsii vlastnykh otnosheniy na Yuge Rossii v 1920-e gody [Cossack-Peasant Self-Government of the NEP Era: Problems of Modernizing Power Relations in the South of Russia in the 1920s]. Novocherkassk, Lik Publ., 2014. 308 p.

16. Perekhov Ya.A. Vlast i kazachestvo: poiski soglasiya (1920-1926 gg.) [Power and the Cossacks. Search for Agreement (1920-1926)]. Rostov-on-Don, Gefest Publ., 1997. 138 p.

17. Pismo kommunista P. Anisimova sekretaryu Terskogo okruzhkoma RKP(b) S.O. Kotlyaru ot 21 yanvarya $1925 \mathrm{~g}$. [Letter from Communist P. Anisimov to Secretary of the Terek District Committee of the Russian Communist Party (Bolsheviks) S.O. Kotlyar on January 21, 1925]. Gosudarstvennyy arkhiv noveyshey istorii Stavropolskogo kraya (GANISK) [State Archive of Modern History of Stavropol Kray], F. 5938, Op. 1, D. 1, L. 32-33.

18. Po voprosu o kazachestve: Rezolyutsiya Plenuma TsK RKP(b) 23-30 aprelya 1925 g. [On the Issue of the Cossacks: Resolution of the Plenum of the Central Committee of the Russian Communist Party (Bolsheviks). April 23-30, 1925]. KPSS v 
rezolyutsiyakh $i$ resheniyakh syezdov, konferentsiy, plenumov TsK [Communist Party of the Soviet Union in Resolutions and Decisions of Congresses, Conferences, Plenums of the Central Committee]. Moscow, Politizdat, 1984, vol. 3, pp. 349-351.

19. Pomatov V.I. Terskoe kazachestvo i vlast $\mathrm{v}$ usloviyakh krizisa $1921 \mathrm{~g}$. [The Terek Cossacks and the Power in the Conditions of the Crisis of 1921]. Nauchnaya mysl Kavkaza [Scientific Thought of Caucasus], 2016, no. 4 (88), pp. 99-105.

20. Protokol № 23 zasedaniya byuro Terskogo okruzhnogo komiteta VKP(b) ot 17 aprelya 1926 g. Rezolyutsiya o rabote Terskogo okruzhnogo otdela OGPU [Minutes no. 23 of the Meeting of the of the All-Union Communist Party (Bolsheviks) Terek District Committee Bureau of April 17, 1926. Resolution on the Work of the Terek District Department of the All-Union State Political Administration]. Gosudarstvennyy arkhiv noveyshey istorii Stavropolskogo kraya (GANISK) [State Archive of Modern History of Stavropol Kray], F. 5938, Op. 1, D. 10, L. 72 ob.

21. Protokol № 35 zasedaniya byuro Terskogo okruzhnogo komiteta VKP(b) ot 6 iyulya 1926 g. Rezolyutsiya o merakh otdela OGPU k kontrrevolyutsionnym i kulatskim gruppirovkam, aktivno proyavlyayushchim sebya $\mathrm{v}$ derevne [Minutes no. 35 of the Meeting of the of the All-Union
Communist Party (Bolsheviks) Terek District Committee Bureau of July 6, 1926. Resolution on the Measures of the All-Union State Political Administration Department Towards CounterRevolutionary and Kulak Groups Actively Manifesting Themselves in the Countryside]. Gosudarstvennyy arkhiv noveyshey istorii Stavropolskogo kraya (GANISK) [State Archive of Modern History of Stavropol Kray], F. 5938, Op. 1, D. 10, L. 108.

22. Rabota soveshchaniya po ozhivleniyu Sovetov Terskogo okruga [Work of the Meeting on Revitalizing the Soviets of Terek District]. Pyatigorsk, Izd-vo Terokrispolkoma, 1925, no. 7. 108 p.

23. Rurk Sh.O. Kak otrabatyvalsya mekhanizm repressiy: vysylka terskikh kazakov v 1920 godu [How the Repression Mechanism Was Worked Out. Expulsion of Terek Cossacks in 1920]. Otechestvennaya istoriya, 2008, no. 5, pp. 97-128.

24. Tkachev E.A. Terskoe kazachestvo v gody revolyutsii i grazhdanskogo protivostoyaniya (19171923): uchastie, politicheskie prioritety, itogi: avtoref. dis. ... kand. ist. nauk [The Terek Cossacks in the Years of Revolution and Civil Confrontation (19171923). Participation, Political Priorities, Results. Cand. hist. sci. abs. diss.]. Pyatigorsk, 2005. 27 p.

25. Searle J. The Construction of Social Reality. New York, Free Press, 1995. 256 p.

\section{Information about the Author}

Andrey V. Baranov, Doctor of Sciences (History), Doctor of Sciences (Politics), Professor, Head of the Department of Political Science and Political Management, Kuban State University, Stavropolskaya St., 149, 350040 Krasnodar, Russian Federation, baranovandrew@mail.ru, https://orcid.org/0000-0001-7109-3062

\section{Информация об авторе}

Андрей Владимирович Баранов, доктор исторических наук, доктор политических наук, профессор, заведующий кафедрой политологии и политического управления, Кубанский государственный университет, ул. Ставропольская, 149, 350040 г. Краснодар, Российская Федерация, baranovandrew@mail.ru,https://orcid.org/0000-0001-7109-3062 